\title{
Molecular Genetics of Breast Cancer
}

\author{
Sigurdur Ingvarsson \\ Institute for Experimental Pathology, University of Iceland, Keldur v/Vesturlandsveg, IS-112 Reykjavik, Iceland \\ Telephone: +354 5674700, Direct telephone: $+354-5674769-123$ Fax: $+354-5673979$, \\ Mobile: +354-8943235E-mail: siguring@hi.is Website: www.keldur.hi.is
}

KEY WORDS BRCA1; BRCA2; breast cancer; CDH1; CHK2; CIN; TP53

\begin{abstract}
Gene and chromosome changes in breast cancer have been analysed using molecular and cytological methods. No single gene alterations are frequent in breast cancer, but several alterations have been detected, in line with multigenetic disease, although malignant progression in relation to gene changes is poorly documented. The most common tumour suppressor gene mutations, detected in about $1 / 4$ of breast tumours are in the TP53 gene, that encodes a transcription factor. Mutations and other alterations in the CDH1 gene, encoding the E-cadherin adhesion protein, in the CHK2 gene, encoding a cell cycle checkpoint kinase, in the BRCA1 and BRCA2 genes, encoding DNA repair proteins and FHIT, encoding a diadenosine hydrolase, will be reviewed. The molecular mechanism behind the frequently detected instability of the genome of breast cancer cells is poorly understood, but some studies have associated it with mutations in the TP53, BRCA1 or BRCA2 genes.
\end{abstract}

\section{INTRODUCTION}

Breast tumours bear all the hallmarks of multiple-gene alterations, where the sequence of events is poorly understood. The genome of breast cancer cells is, in general, unstable and is mostly classified as chromosome instability (CIN). The understanding of CIN in breast tumours is rather poor, but can be explained in a minority of tumours, i.e. in carriers of BRCA1 and BRCA2 mutations, due to an improper DNA repair mechanism (Ingvarsson 1998; Tirkkonen 1997). The frequency of individual gene alterations in breast tumours is rather low, but several gene alterations have been detected. These are amplifications of oncogenes and mutations or other alterations in tumour suppressor genes (TSGs). Three of the chromosome regions that are amplified in breast tumours carry rather well characterized oncogenes; MYC, CCND1 (encoding cyclinD1) and HER2. The frequency of these amplifications is rather low, or $15-25 \%$, respectively. The studies on HER2 amplification and Her2 overexpression are a good example of how information from molecular biology has been useful in therapeutics, as today specific antibodies against Her2 can be used for breast cancer treatment (Slamon 2001). Even though TP53 is only mutated in about $1 / 4$ of breast tumours it is the gene that is most frequently mutated and germ-line mutations are linked to the $\mathrm{Li}$-Fraumeni syndrome (LFS), where breast cancer is one of the diseases. Germ-line mutations in CHK2 can cause a phenotype similar to LFS and are considered to be low penetrance breast cancer sequence variants. Rare somatic mutations of CHK2 in breast tumours have also been described. In this review the focus will be on genomic instability and alterations of TSGs in breast cancer.

\section{GENOMIC INSTABILITY}

It has been known for some time that the genomes of breast cancer cells are unstable. This was originally based on flow cytometry, and the instability of the complete genome was scored as aneuploidy, which is detected in about $70 \%$ of breast cancers (Hedley 1987). More recently, methods such as comparative genome hybridization (CGH), fluorescence in situ hybridization (FISH), chromosome painting and microsatellite marker analysis have been helpful in analysing genomic instability, and can be used to analyse the genome in part or whole (Tirkkonen 1997; Ingvarsson 1998; Sigurdsson 2000; Lingle 2002).

Alterations at some chromosome regions are frequently detected in tumours with an unstable genome, while alterations at other chromosomes seem to be unrelated to genetic instability. One would expect that frequent losses at certain chromosome regions not associated with genetic instability to involve a TSG, a loss which gives growth advantage to the cell, resulting in clonal expansion. The situation is not as clear when losses at certain chromosome regions are associated with genetic instability. Loss at these chromosome regions could reflect the unstable nature of the breast cancer genome, and therefore these losses could serve as markers for genetic 
instability. This does not exclude the growth advantage of the breast tumour cells, due to TSG elision, being of importance for the clonal selection of these chromosomal losses.

In our studies, when analysing the association of $\mathrm{LOH}$ at one chromosome region to $\mathrm{LOH}$ at other loci, chromosomes $3 p, 6 q$ and $8 p$ are the regions most frequently altered in tumours with an unstable genome (Table 1). In contrast, $\mathrm{LOH}$ at chromosome $16 \mathrm{q}$ is not associated to an unstable genome, even though this is the chromosome region most frequently altered in sporadic breast cancer (Table I, Skirnisdottir 1995). Chromosome $16 \mathrm{q} \mathrm{LOH}$ also differs from chromosomal losses associated with genome instability when compared to clinicopathological factors, i.e. while chromosome 3p, 6q and 8p losses are associated with aneuploidy, high S-phase and reduced patient survival, chromosome $16 \mathrm{LOH}$ does not show this association and is in contrast associated with low S-phase and elevated patient survival (Bragadottir 1995; Eiriksdottir 1995a; Hansen 1998; Sigbjornsdottir 2000; Skirnisdottir 1995). In addition, while LOH at 3 p shows association with low estrogen receptor (ER) and progesterone receptor (PR) expression, LOH at 16q shows association with high PR (Eiriksdottir 1995a; Skirnisdottir 1995). In general the genome is more stable in lobular than ductal breast cancer, with the exception of $\mathrm{LOH}$ at $16 \mathrm{q}$, which is detected with higher LOH in lobular breast cancer (Huiping 1999a). No definitive answer has yet been found to the question of whether $\mathrm{LOH}$ of $3 p, 6 q, 8 q$ and some other chromosomes are only markers for genome instability or whether true TSGs of importance for malignant progression of breast cancer are located there. The $3 \mathrm{p}$ region is not only frequently altered in breast cancer but is among the most frequently lost regions in many types of cancer. However, it has been the most difficult region in which to find TSGs and it has been hypothesized that combined functional loss of several TSGs located at 3 p contributes to tumour pathogenesis (Huebner 2001).

The only gene localized and expressed at an fragile site in the genome and analysed to some extensity in relation to tumour growth is FHIT, located at the FRA3B. Its protein product is a diadenosine triphosphate hydrolase, and diadenosine is presumably important for cell growth and apoptosis (Barnes 1996). Even though classical point mutations of the FHIT gene are not found in breast cancer, relatively high levels of abnormalities are detected, including deletions, methylation, and altered or reduced expression (Ingvarsson 2001; Huiping 2000; Zochbauer-Muller 2001). The relevance of these FHIT alterations for breast cancer pathogenesis is not clear, but they have been associated with reduced patient survival and genome instability (Ingvarsson 2001). A high frequency of alterations at FHIT is detected in sporadic tumours, and at a higher frequency in BRCA2 tumours (Ingvarsson 1999). This could

Table1: Association of $\mathrm{LOH}$ at a certain chromosome region to $\mathrm{LOH}$ at a given chromosome region. *95\% Confidence Interval (CI), **99\% CI, ***99.9\% CI. (Bragadottir 1995, Eiriksdottir 1995a, b and 1998, Gudmundsson 1995a, Huiping 1998, Kristjansson 1998, Ragnarsson 1996, Sigbjornsdottir 2000, Skirnisdottir 1995).

\begin{tabular}{|c|c|c|c|c|c|c|c|c|c|c|c|c|c|c|}
\hline & $1 p$ & $3 p$ & $6 q$ & $7 q$ & $8 p$ & $9 p$ & $11 p$ & $11 q$ & $13 q$ & $16 q$ & $17 p$ & $17 q$ & $18 q$ & $20 q$ \\
\hline $1 \mathrm{p}$ & $\ldots$ & $* * *$ & $* *$ & $* *$ & $*$ & $*$ & & & & & & $*$ & $* *$ & $* *$ \\
\hline $3 p$ & $* * *$ & $\ldots$ & $* * *$ & $* *$ & $* * *$ & $*$ & $* * *$ & $*$ & & & & & & $* *$ \\
\hline $6 q$ & $* *$ & $* * *$ & $\ldots$ & & $* * *$ & $* * *$ & & $*$ & & & $*$ & $*$ & & $* * *$ \\
\hline $7 q$ & $* *$ & $* *$ & & $\ldots$ & $* *$ & $*$ & & & $*$ & & & $*$ & $*$ & \\
\hline $8 p$ & $*$ & $* * *$ & $* * *$ & $* *$ & $\ldots$ & $* * *$ & $* *$ & & $* * *$ & & $*$ & & & $* * *$ \\
\hline $9 p$ & $*$ & $*$ & $* * *$ & $*$ & $* * *$ & $\ldots$ & & & & & & & $*$ & $* *$ \\
\hline $11 \mathrm{p}$ & & $* * *$ & & & $* *$ & & $\ldots$ & & & & & $* * *$ & & \\
\hline $11 \mathrm{q}$ & & $*$ & $*$ & & & & & $\ldots$ & & & & & & \\
\hline $13 q$ & & & & $*$ & $* * *$ & & & & $\ldots$ & & & & $* *$ & $* *$ \\
\hline $16 q$ & & & & & & & & & & $\ldots$ & & & & \\
\hline $17 p$ & & & $*$ & & $*$ & & & & & & $\ldots$ & & & \\
\hline $17 q$ & $*$ & & $*$ & $*$ & & & $* * *$ & & & & & $\ldots$ & $*$ & $* * *$ \\
\hline $18 \mathrm{q}$ & $* *$ & & & $*$ & & $*$ & & & $* *$ & & & $*$ & $\ldots$ & \\
\hline $20 \mathrm{q}$ & $* *$ & $* *$ & $* * *$ & & $* * *$ & $* *$ & & & $* *$ & & & $* * *$ & & $\ldots$ \\
\hline
\end{tabular}


merely reflect the unstable nature of the fragile site in the breast tumour cell, but it is also possible that FHIT plays a tumour suppressor role. It may be questioned if the fragile sites in the genome are more sensitive to alterations in a BRCA1 and BRCA2 mutation background, due to the DNA repair role of Brca1 and Brca2. This could be part of the story, but not the only explanation. When comparing our LOH data from chromosomes that carry the most common fragile sites in the genome, FRA3B, FRA16D and FRA6E, only chromosomes $3 p$ and $6 q$ show elevated LOH in BRCA2 associated tumours compared to sporadic breast tumours, but not chromosome 16q (Bergthorsson 1995, 1998; Ingvarsson 1998, 1999). Similarly, there is higher LOH at chromosome $8 \mathrm{p}$ in BRCA2 associated tumours compared to sporadic tumours, but this chromosome region is considered to be stable (Sigbjornsdottir 2000). Even though the information on the link between the biochemical function of the Fhit and tumour pathogenesis is limited, there is growing evidence from cell and mouse models for the role of FHIT as a tumour suppressor (Ji 1999; Sard 1999; Siprashvili 1997; Zanesi 2001). And even though FHIT loss is associated with genomic instability, there is no data suggesting that inactivation of FHIT is causing this instability; it could equally well be a consequence of it.

In most cases the reasons for genome instability in breast tumour cells are unknown. Amplifications of centrosomes have been shown to be associated with genome instability, and are detected in the early progression of breast cancer, but the cause of the centrosome amplification remains poorly understood (Lingle 2002). Since the TP53 is considered to be the guardian of genome integrity it is not surprising that genome instability is associated with TP53 mutations. This is confirmed by some, but not all, studies (Gretarsdottir 1998; Lingle 2002; Sigurdsson 2000). The genome instability of breast tumours in BRCA1 and BRCA2 mutation carriers is well documented, and fits well with the idea that the protein products are operating in DNA repair (Ingvarsson 1998; Tirkkonen 1997). It has been suggested that CIN provoked by BRCA2 deficiency is the result of incorrect routing of double strand DNA break repair processing down inappropriate pathways, rather than the failure of repair per se (Tutt 2001). Another type of genome instability, i.e. replication error or microsatellite instability, presumably due to lack of mismatch repair, which is defined better molecularly than CIN, is found only in a minority of breast tumours, less than $2 \%$. It was concluded that this instability is a rare somatic event in the tumour progression of breast cancer (Huiping 1999b).

\section{ABNORMALITIES OF E-CADHERIN AND LOBULAR BREAST CANCER}

In a Belgian-Dutch study, more than half of lobular breast tumours show mutations in the Ecadherin gene, CDH1 (Berx 1995; Berx 1996). Mutations of CDH1 in lobular breast cancer were confirmed in an Icelandic study (Huiping 1999a). The mutations are distributed over the CDH1 gene, mainly in the part corresponding to the extracellular region of E-cadherin, which is responsible for cell adhesion, but also in the transmembrane domain, the intracellular part and the precursor sequence. The mutations are believed to give rise to nonfunctional proteins with corresponding lack of cell adhesion. It seems that CDH1 is behaving like a typical TSG in a large fraction of lobular breast cancer, with a double hit mechanism, i.e. mutation of one and deletion of the other copy of the gene (Huiping 1999a). The situation is different in ductal breast cancer, but several studies have shown loss of one gene copy and reduced expression of Ecadherin, which is associated with clinicopathological factors and patient survival (Huiping 1999a; Asgeirsson 2000). Inactivation of E-cadherin expression by methylation, converting chromatin into a transcriptionally repressive state, is documented for both lobular and ductal breast cancer (Droufakou 2001; Graff 1995; Nass 2000). It is possible that the CDH1 is de-activated by a double hit mechanism in lobular breast cancer, while haplo-insufficiency could explain the participation in the malignant progression of ductal breast cancer. This could mean that the progression of precancerous cells toward malignant ductal carcinoma is more sensitive to reduced E-cadherin activity than progression of precancerous cells towards lobular carcinoma, where complete loss is needed. The analysis of CDH1 mutations is clearly describing the molecular difference between lobular and ductal breast cancer. The difference between these two histological types of breast cancer is also detected at genome level, since most chromosomes analysed so far show higher 
$\mathrm{LOH}$ in ductal than in lobular breast cancer (Huiping 1999a). This indicates higher CIN in ductal breast cancer than in lobular breast cancer (see earlier), with the exception of chromosome 16q22.1, where the CDH1 gene is located, as this chromosome region shows higher loss in lobular breast cancer (Huiping 1999a).

\section{THETP53 AND CHK2 GENES}

TP53 is somatically mutated in about $25 \%$ of breast tumours and germ-line mutations have been described in the LFS, where one of the increased susceptibility disease phenotypes is breast cancer (Malkin 1990; Srivastava 1990). The TP53 encodes the p53 transcription factor important for cell cycle checkpoints and

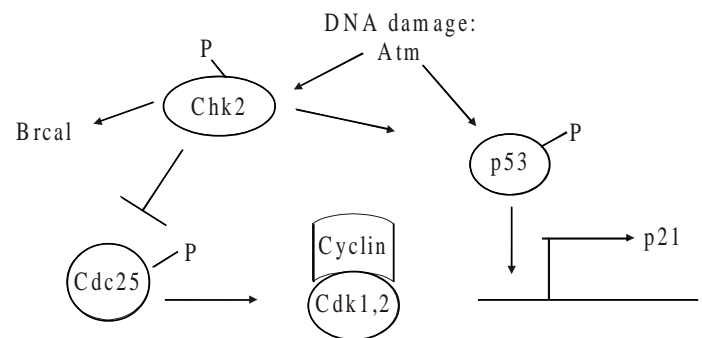

Degradation

14-3-3 binding

Fig. 1. Simplified pathways of the p53 and Chk2 in cell cycle checkpoints. The Chk2 is phosphorylated by the Atm kinase upon DNA damage. Targets of Chk2 are Brca1, Cdc25 and p53, resulting in deactivation of $\mathrm{Cdc25}$ and stabilization of p53, leading to a halt in the cell cycle. See text for details and references.

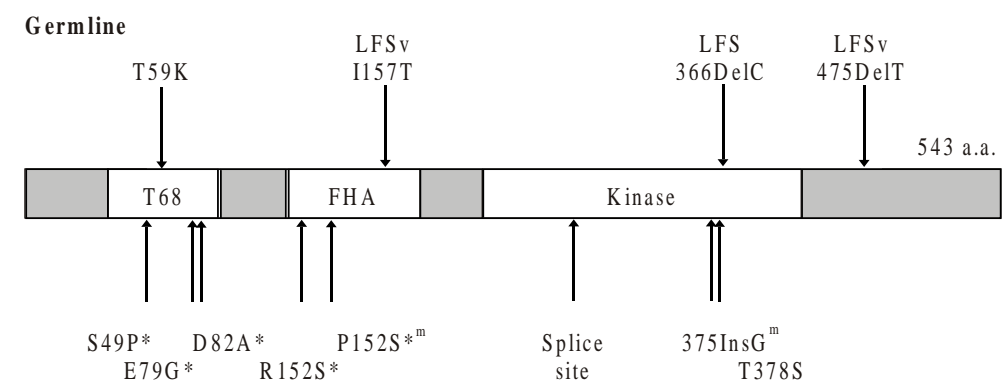

Som atic

Fig. 2. Map of Chk2 and the detected mutations in breast cancer (Bell 1999, Ingvarsson 2002, Sullivan 2002). Mutations at the top of the figure are germline while mutations below are somatic. LFS: Li-Fraumeni syndrome, LFSv: LFS variant, T68: threonine phosphorylation site, FHA: fork head associated domain, *BRCA1 associated tumours, medullary breast cancer.

induction of apoptosis. One well characterized pathway in the G1 cell cycle checkpoint activation involves transcriptional activation and subsequent expression of the cyclin-dependent kinase inhibitor p21 (Fig. 1). Upon DNA damage or other stress environment in the cell, p53 accumulates, transactivates the gene encoding the p 21 inhibitory protein, and the cell halts in the $\mathrm{G} 1$ phase of the cell cycle. One of the known pathways of p53 induction of apoptosis is by transcriptional activation of the gene encoding Bax 1, an inducer of apoptosis. Interaction of p53 with Brca1 and other proteins important for DNA repair has been reported, but functional evidence for the role of p53 in DNA repair is still limited. A feasible model is that p53 is important for blocking the cell from entering the S-phase of the cell cycle upon cell damage, and induces apoptosis if the damage is overwhelming. With failure of p53 normal function due to mutation, there is a risk of accumulation of genetic instability and mutations in additional genes.

TP53 somatic mutations have been associated with reduced survival of breast cancer patients (Borresen 1995). The majority of TP53 mutations are missence, in contrast to mutations in several other TSGs, where the majority of mutations result in a truncated protein. Some of the TP53 mutations are dominant negative, presumably due to incompetent transcription factor, if one or more mutant copies of the protein are included in the p53 tetrameric form. About 1,400 TP53 mutations in relation to breast cancer are listed in the IARC database. The germline mutation spectrum is slightly different from the somatic pattern, in line with endogenous 
mutagenic processes, such as methylated cytosines or polymerase errors (Olivier 2001). The somatic mutation spectrum of TP53 in breast tumours is similar to other cancers, with the exceptions of lower frequency of certain transversions known to be strongly associated with environmental carcinogens and higher frequency of transitions (Olivier 2001). Yet environmental factors seem to affect the mutation pattern of TP53 in breast cancer, based on different mutation patterns in different populations (Olivier 2001). Furthermore, a high frequency of codon 163 mutation of the TP53 is detected in breast tumours, particularly in BRCA1 mutational background (Crook 1997, 1998; Greenblatt 2001). The mutation spectrum of TP53 in BRCA1 and BRCA2 carriers is different compared to sporadic tumours, which is consistent with a repair function of Brcal and Brca2 (Greenblatt 2001). The p53 mutants are presumably selected during the malignant progression in the genetic background of BRCA1 and BRCA2 associated tumours.

Somatic and germline mutations in the $\mathrm{CHK} 2$ gene have been described more recently in relation to breast cancer, suggesting that loss of Chk2 is functionally equivalent to TP53 mutations, while CHK2 mutation frequency is lower than TP53 mutation frequency (Bell 1999; Ingvarsson 2002; Sullivan 2002). Germline mutations of CHK2 have been found in $\mathrm{Li}$ Fraumeni and Li-Fraumeni-like families, and by population screening of breast cancer patients (Bell 1999; Ingvarsson 2002; Sullivan 2002) (Fig. 2). Mutations of CHK2 in breast cancer are distributed over different domains of the gene and are mainly missence, but also truncation mutations (Fig. 2). The germline variants of the CHK2 analysed so far by population screening seem to be low penetrance alleles conferring susceptibility to breast cancer (Ingvarsson 2002; Meijers-Heijboer 2002). Several such susceptibility alleles have been previously suggested, but among them the CHK2 low-penetrance alleles probably show the most convincing statistical significance (Dunning 1999; Meijers-Hejboer 2002). Populationbased analysis of the 366delC mutation, that abolishes kinase activity, indicated a 5\% frequency in individuals with breast cancer, and a twofold and tenfold increased risk of breast cancer in females and males respectively (Meijers-Heijboer 2002). Even though germline variants of the CHK2 seem to confer an increased risk of breast cancer on the background of some genotypes, they do not seem to confer increased cancer risk in BRCA1 or BRCA2 mutation carriers (Ingvarsson 2002; Meijers-Heijboer 2002). Still, tumours in BRCA1 carriers have a relatively high frequency of somatic CHK2 mutations as well as tumours in patients with medullary carcinoma (Sullivan 2002). This is of particular interest, since TP53 somatic mutations are also found at a high level in BRCA1 tumours (Crook 1997, 1998; Greenblatt 2001). These findings of somatic mutations in cell cycle checkpoint genes, like TP53 and CHK2, are in line with the theory that they increase the rate of tumorigenesis in BRCA1 associated tumours (see later).

The Chk2 is activated upon DNA damage via phosphorylation by Atm kinase (Falck 2001; Matsuoka 1998, 2000; Melchionna 2000). The targets of Chk 2 phosphorylation are Brca1, Cdc25 and p53 (Blasina 1999; Chehab 2000; Falck 2001; Furnari 1999; Hirao 2000; Lee 2000; Shieh 2000). The phosphorylation of p53 stabilizes this transcription factor (Chehab 2000; Hirao 2000; Shieh 2000). The phosphorylation of the Cdc 25 phosphatases results in their degradation or binding to 14-3-3 protein and subsequent export of $\mathrm{Cdc} 25$ from the nucleus to the cytoplasm (Blasina 1999; Falck 2001; Furnari 1999). Both the stabilization of p53 and deactivation of $\mathrm{Cdc} 25$ due to Chk2 activation can result in braking the cell cycle (Fig. 1).

\section{BRCA1 AND BRCA2}

BRCA1 and BRCA2 are the two major breast cancer susceptibility genes and responsible for the dominantly inherited disease (Miki 1994; Wooster 1995). However, they only explain less than $10 \%$ of breast cancers. The majority of breast cancers are considered to be sporadic, where somatic mutations have a major role, or are due to the combined effects of low-penetrance sequence variants and genetic background. The original estimate of BRCA mutation penetrance was based on high risk families but more recent population data suggest lower penetrance, or $37 \%$ at the age of 70 years (Thorlacius 1998).

The mechanism of inactivation in tumours is considered to be a double hit, a germ-line mutation and a somatic deletion (Smith 1992; Gudmundsson 1995b). However, there is a lack of experimental data to clarify whether losses of the W.T. chromosomes are a prerequisite for non- 
or abnormal function of the proteins, or whether dominant negative or haplo-insufficient mechanisms can explain the original pathogenesis (Fan 2001).

Since germline mutations of BRCA1 and BRCA2 are relatively frequent in relation to familial breast cancer, the rarity of somatic mutations has been regarded as surprising (Khoo 1998; Signori 2001). This situation is different from the TP53 mutation story, where somatic mutations are relatively common and germ-line mutations are rare. Is there some prevention of the molecular mechanism leading to somatic mutations of BRCA1 and BRCA2 or do the mutations not give growth advantage for the cells? Is there a particular time frame in normal tissue maturation, after which somatic BRCA1 and BRCA2 mutations are not selected during sporadic breast tumour development, although gene silencing mechanisms and large rearrangements and deletions can influence tumour progression? Even though somatic mutations are rare in BRCA1, it is frequently deleted and expression is decreased in breast tumours, although not always by a known mechanism (Thompson 1995; Wilson 1999). Hypermethylations at the promoter region can partly explain the BRCA1 downregulation in sporadic breast tumours (Catteau 1999; Rice 1998).

The Brca1 and Brca2 proteins participate in the BASC (Brca1 associated genome surveillance complex). They are multifunctional proteins involved in complex protein-protein interactions, DNA repair, DNA recombination, transcription and cell cycle checkpoint control. Brca1 is phosphorylated by several kinases upon DNA damage (Borg 2001). The factors binding to Brcal are both specific transcriptional factors and factors involved in chromatin remodelling, suggesting both positive and negative regulation of transcription. The Brca proteins participate in homologous recombination repair. Mainly active in $\mathrm{S}$ and $\mathrm{G} 2$ phases of the cell cycle, they are essential for preserving chromosome structure, suggesting that, in their role as tumour suppressors, they behave as caretakers, suppressing genome instability. While the role of Brca 1 and Brca 2 in homologous recombination repair of double strand DNA breaks is well established, more work is needed to clarify whether they are regulators of cell cycle events independent of their role in DNA repair.

Molecular and pathological data suggest not only a difference between BRCA 1 and BRCA2 associated tumours, but also between them and sporadic tumours. BRCA1 and BRCA2 tumours are more aggressive than sporadic tumours as indicated by S-phase, mitosis, aneuploidy, genomic instability and pathological appearance (Borg 2001; Breast cancer linkage consortium 1997). Other characteristics of BRCA1 tumours are low ER content, elevated lymphocyte infiltration and appearance of medullary phenotype (Marcus 1996; Johannsson 1997). The gross genomic instability detected in BRCA1 and BRCA2 tumours fits well with their documented function in DNA repair (Ingvarsson 1998; Tirkkonen 1997). Moreover, the chromosome aberration profiles of BRCA1 and BRCA2 tumours differ from each other and from other breast cancers, suggesting that specific genetic pathways operate in the progression of these inherited tumours (Ingvarsson 1998; Tirkkonen 1997). A functional support of the discrimination between BRCA1, BRCA2 and sporadic breast tumours is also evident from genome-wide gene expression profiles (Hedenfalk 2002).

It can be hypothesized that in the early stage of BRCA1 and BRCA2 pathogenesis, cells progress through a preliminary crisis phase with massive apoptosis due to accumulation of genetic changes. Further gene alterations, for instance in TP53 or CHK2, rescue the cell from this senescence phase, and progression is towards reduced apoptosis, enhanced cell growth and a fully malignant phenotype (Crook 1997; Greenblatt 2001; Sullivan 2002). Even though p53 mutations are not as frequent in BRCA2 as in BRCA1 associated tumours, overexpression of p53 is detected, suggesting that in BRCA2 mutation carriers the $\mathrm{p} 53$ pathway is deregulated by some other mechanisms in addition to mutation (Crook 1998; Eiriksdottir 1998; Greenblatt 2001; Gretarsdottir 1998). Mouse knockout experiments support the hypothesis of preliminary crisis phase, and it has been shown that inactivation of $\mathrm{p} 53$, or other checkpoint proteins like Bub1 and Mad3L, is of importance in tumour progression in mouse cells lacking Brca (Lee 1999). In general, there are multiple genetic changes in mammary tumours of Brcal knockout mice, similar to those detected in human breast cancer (Brodie 2001). 


\section{CONCLUSION}

Frequent gains and losses have been detected in the genome of breast cancer cells. For most of the altered chromosome regions it remains unanswered which gene alterations are involved in the pathogenesis of breast cancer, or if some of these regions reflect only the unstable nature of the genome. Presumably there are several genes from these chromosome regions, so far not characterized, that are of importance for breast cancer pathogenesis. Although somatic changes are distributed among several genes, where frequency of single gene alterations is low, breast cancer is mainly a sporadic disease; highly penetrant alleles only explain a small fraction of breast cancer, and the role of lowpenetrance alleles in a certain genetic background remains a puzzle. Even though TP53 alterations only partly explain the malignant phenotype in the breast, and in a fraction of tumours, the mutations are well characterized and the role of p53 as a tumour suppressor is well documented. Germ-line mutations are detected in several genes, where BRCA1 and BRCA2 are the major breast cancer susceptibility genes, TP53 to a lesser extent, and germline variants of CHK2, the newest member of TSGs in breast cancer pathogenesis seem to be of low penetrance. The role of Chk2 in the malignant progression of breast should be established in the nearest future. Despite intensive efforts in the study of Brcal and Brca2 loss of function in breast tumour pathogenesis, little is known about their role in the biology of epithelial tissues. Additional biochemical data on the biology of Fhit in relation to tumour pathogenesis would help the process of understanding its role in breast cancer progression. Further studies will doubtless elucidate new genes of interest in normal and transformed cells of the breast epithelium and reveal the function of their protein products in normal and malignant growth.

\section{REFERENCES}

Asgeirsson KS, Jonasson JG, Tryggvadottir L, Olafsdottir K, Sigurgeirsdottir JR, Ingvarsson S, Ögmundsdottir $\mathrm{H}$ 2000. Altered expression of E-cadherin in breast cancer: patterns, mechanisms and clinical significance. Eur J Cancer, 36: 1098-1106.

Barnes LD, Garrison PN, Siprashvili Z, Guranowski A Robinson AK, Ingram SW, Croce CM, Ohta M, Hubner K 1996. Fhit, a putative tumor suppressor in humans, is a diadenosine $5,, 5$, , 'P1,P3triphospate hydrolase. Biochem, 35: 1152911535.

Bell D, Varley JM, Szydlo TE, Kang DH, Wahrer DCR, Shannon KE, Lubratovich M, Verselis SJ, Isselbacher KJ, Fraumeni JF, Birch JM, Li FP, Garber JE, Haber DA 1999. Heterozygous germ line hCHK2 mutations in Li-Fraumeni syndrome. Science, 286: 2528-2531.

Bergthorsson JT, Eiriksdottir G, Barkardottir RB, Egilsson V, Arason A, Ingvarsson S 1995. Linkage analysis and allelic imbalance in human breast cancer kindreds using microsatellite markers from the short arm of chromosome 3. Hum Genet, 96: 437-443.

Bergthorsson JT, Johannsdottir J, Jonasdottir A, Eriksdottir G, Egilsson V, Ingvarsson S, Barkardottir RB, Arason A 1998. Chromosome imbalance at the 3 p14 region in human breast tumors; High frequency in patients with inherited predisposition due to BRCA2. Eur J Cancer, 34: 142-147.

Berx G, CletonJansen AM, Nollet F, deLeeuw WJF, vandeVijiver MJ, Cornelisse C, vanRoy F 1995. Ecadherin a tumour / invasion suppressor gene mutated in human lobular breast cancers. EMBO J, 14: 6107-6115.

Berx G, CletonJansen AM, Strumane K, deLeeuw WJF, Nollet F, vanRoy F, Cornelisse C 1996. E-cadherin is inactivated in a majority of invasive human lobular breast cancer by truncation mutations throughout its extracellular domain. Oncogene, 13: 1919-1925.

Blasina A, deWeyer IV, Laus MC, Luyten WH, Parker AE, McGowan CH 1999. A human homologue of the checkpoint kinase Cds1 directly inhibits Cdc25 phosphatase. Curr Biol, 9: 1-10.

Borg A 2001. Molecular and pathological characterization of inherited breast cancer. Sem Cancer Biol, 11: $375-385$.

Borresen AL, Andersen TI, Eyfjord JE, Cornelis RS, Thorlacius S, Borg A, Johansson U, Theillet C, Scherneck S, Hartman S, Cornelisse CJ, Hovig E, Devilee P 1995. TP53 mutations and breast-cancer prognosis - particularly poor survival rates for cases with mutations in the zinc-binding domains. Genes Chrom Cancer, 14: 71-75.

Bragadottir G, Eiriksdottir G, Sigurdsson A, Barkardottir RB, Gudmundsson J, Jonasson JG, Ingvarsson S 1995. Loss of heterozygosity at chromosome 6q correlates with tumor progression and patient survival. Int J Oncol, 7: 871-876.

Breast Cancer Linkage Consortium 1997. Pathology of familial breast cancer: differences between breast cancers in carriers of BRCA1 or BRCA2 mutations and sporadic cases. Lancet, 349: 1505-1510.

Brodie SG, Xu XL, Qiao WH, Li WM, Cao L, Deng CX 2001. Multiple genetic changes are associated with mammary tumorigenesis in Brcal conditional knockout mice. Oncogene, 20: 7514-7523.

Catteau A, Harris WH, Xu CF, Solomon E 1999. Methylation of the BRCA1 promoter region in sporadic breast and ovarian cancer: correlation with disease characteristics. Oncogene, 18: 1957-1965.

Chehab NH, Malikzay A, Appel M, Halazonetis TD 2000. Chk2/hCds 1 functions as a DNA damage checkpoint in $\mathrm{G}(1)$ by stabilizing p53. Genes Dev, 
14: $278-288$.

Crook T, Crossland S, Crompton MR, Osin P, Gusterson BA 1997. P53 mutations in BRCA1-associated familial breast cancer. Lancet, 350: 638-639.

Crook T, Brooks LA, Crossland S, Osin P, Barker KT, Waller J, Philp E, Smith PD, Yulug I, Peto J, Parker G, Allday MJ, Crompton MR, Gusterson BA 1998. p53 mutation with frequent novel codons but not a mutation phenotype in BRCA1- and BRCA2associated breast tumours. Oncogene, 17: 16811689.

Droufakou S, Deshmane V, Roylance R, Hanby A, Tomlinson I, Hart IR 2001. Multiple ways of silencing E-cadherin gene expression in lobular carcinoma of the breast. Int J Cancer, 92: 404408.

Dunning AM, Healey CS, Pharoah PD, Teare MD, Ponder BA, Easton DF 1999. A systematic review of genetic polymorphisms and breast cancer risk Cancer Epidemiol Biomark Prev, 8 : 843-854.

Eiriksdottir G, Bergthorsson JT, Sigurdsson H, Gudmundsson J, Skirnisdottir S, Egilsson V, Barkardottir RB, Ingvarsson S 1995a. Mapping of chromosome 3 alterations in human breast cancer using microsatellite PCR markers: correlation with clinical variables. Int J Oncology, 6: 369-375.

Eiriksdottir G, Sigurdsson A, Jonasson JG, Agnarsson BA, Sigurdsson H, Gudmundsson J, Bergthorsson JT, Barkardottir RB, Egilsson V, Ingvarsson S 1995b. Loss of heterozygosity on chromosome 9 in human breast cancer: association with clinical variables and genetic changes at other chromosome regions. Int J Cancer, 64: 378-382.

Eiriksdottir G, Barkardottir RB, Agnarsson BA, Johannesdottir G, Olafsdottir K, Egilsson V, Ingvarsson S 1998. High incidence of loss of heterozygosity at chromosome $17 \mathrm{p} 13$ in breast tumours from BRCA2 mutation carriers. Oncogene, 16: 21-26.

Falck J, Mailand N, Syljuasen RG, Bartek J, Lukas J 2001. The ATM-Chk2-Cdc25A checkpoint pathway guards against radioresistant DNA synthesis. Nature, 410: 842-847.

Fan SJ, Yuan RQ, Ma YX, Meng QH, Goldberg ID, Rosen EM 2001. Mutant BRCA1 genes antagonize phenotype of wild-type BRCA1. Oncogene, 20: 8215-8235.

Furnari B, Blasina A, Boddy MN, McGowan CH, Russel $P$ 1999. Cdc25 inhibited in vivo and in vitro by checkpoint kinases Cds1 and Chk1. Mol Biol Cell, 10: $833-845$.

Graff JR, Herman JG, Lapidus RG, Chopra H, Xu R, Jarrard DF, Isaacs WB, Pitha PM, Davidson NE, Baylin SB 1995. E-cadherin expression is silenced by DNA hypermethylation in human breast and prostate carcinomas. Cancer Res, 55: 5195-5199.

Greenblatt MS, Chappuis PO, Bond JP, Hamel N, Foulkes WD 2001. TP53 mutations in breast cancer associated with BRCA1 or BRCA2 germ-line mutations. Cancer Res, 61: 4092-4097.

Gretarsdottir S, Thorlacius S, Valgardsdottir R, Gudlaugsdottir S, Sigurdsson S, Steinarsdottir M, Jonasson JG, Anamthawat-Jonsson K, Eyfjord JE 1998. BRCA2 and p53 mutations in primary breast cancer in relation togenetic in stability. Cancer
Res, 58: 859-862.

Gudmundsson J, Barkardottir RB, Eiriksdottir G, Arason A, Egilsson V, Ingvarsson S 1995a. Loss of heterozygosity at chromosome 11 in breast cancer: association of prognostic factors with genetic alterations. Br J Cancer, 72: 696-701.

Gudmundsson J, Johannesdottir G, Bergthorsson JT, Arason A, Ingvarsson S, Egilsson V, Barkardottir RB 1995b. Different tumor types from BRCA2 carriers show wild-type chromosome deletions on 13q12-q13. Cancer, Res, 55: 4830-4832.

Hansen LL, Yilmaz M, Overgaard J, Andersen J, Kruse TA 1998. Allelic loss of 16q23.2-24.2 is an independent marker of good prognosis in primary breast cancer Cancer Res, 58: 2166-2169.

Hedenfalk I, Duggan D, Chen Y 2002. Gene-expression profiles in hereditary breast cancer. Adv Anat Pathol, 9: 1-4.

Hedley DW, Rugg CA, Gelber RD 1987. Association of DNA index and S-phase fraction with prognosis of nodes positive early breast cancer. Cancer Res, $\mathbf{4 7}$ : 361-366.

Hirao A, Kong YY, Matsuoka S, Wakeham A, Ruland J, Yoshida H, Liu D, Elledge SJ, Mak TW 2000. DNA damage-induced activation of $\mathrm{p} 53$ by the checkpoint kinase Chk2. Science, 287: 1824-1827.

Huebner K 2001. Tumor suppressors on 3p: A neoclassic quartet. Proc Natl Acad Sci USA, 98: 14763-14765.

Huiping C, Eiriksdottir G, Sigurdsson A, Sigurgeirsdottir JR, Barkardottir RB, Egilsson V, Ingvarsson S 1998. High frequency of LOH at chromosome 18q in human breast cancer: association with high Sphase fraction and low progesterone receptor content. Anticancer Res, 18: 1031-1036.

Huiping C, Sigurgeirsdottir JR, Jonasson JG, Eiriksdottir G, Johannesdottir JT, Egilsson V, Ingvarsson S 1999a. Chromosome alterations and E-cadherin gene mutations in human lobular breast cancer. $\mathrm{Br}$ J Cancer, 81: 1103-1110.

Huiping C, Jonasson JG, Agnarsson BA, Sigbjornsdottir BI, Huebner K, Ingvarsson S 2000. Analysis of the fragile histidine triad (FHIT) gene in lobular breast cancer. Eur J Cancer, 36 : 1552-1557.

Huiping C, Johannsdottir JT, Arason A, Olafsdottir GH, Eiriksdottir G, Egilsson V, Ingvarsson S 1999b. Replication error in human breast cancer: Comparison with clinical variables and family history of cancer. Oncol Rep, 6: 117-122.

Ingvarsson S, Geirsdottir EK, Johannesdottir G, Sigbjornsdottir BI, Eiriksdottir G, Ragnarsson G, Agnarsson BA, Gudmundsson J, Jonasson JG, Sigurdsson A, Egilsson V, Barkardottir RB 1998. High incidence of loss of heterozygosity in breast tumors from carriers of the 999del5 BRCA2 mutation. Cancer Res, 58: 4421-4425.

Ingvarsson S, Agnarsson BA, Sigbjornsdottir BI, Kononen J, Kallioniemi OP, Barkardottir RB, Kovatich A, Schwarting R, Hauck WW, Huebner K, McCue PA 1999. Reduced Fhit expression in sporadic and BRCA2-linked breast carcinomas. Cancer Res, 59: 2682-2689.

Ingvarsson S, Sigbjornsdottir BI, Huiping C, Jonasson JG, Agrasson BQ, 2001. Alterations of the FHIT gene in breast cancer: Association with tumor progression and patient survival. Cancer Detect 
Prev, 25: 292-298.

Ingvarsson S, Sigbjornsdottir BI, Huiping C, Hafsteinsdottir SH, Ragnarsson G, Barkardottir RB, Arason A, Egilsson V, Bergthorsson JT 2002. Mutation analysis of the CHK2 gene in breast carcinoma and other cancers. Breast Cancer Res, 4:R4.

Ji L, Fang B, Yen N, Fong K, Minna JD, Roth JA 1999. Induction of apoptosis and inhibition of tumorigenicity and tumor growth by adenovirus vector-mediated fragile histidine triad (FHIT) gene overexpression. Cancer Res, 59: 3333-3339.

Johannsson OT, Idvall I, Anderson C, Borg A, Barkardottir RB, Egilsson V, Olsson H 1997. Tumor biological features of BRCA1-induced breast and ovarian cancer. Eur J Cancer, 33: 362-371.

Khoo US, Ozcelik H, Cheung ANY, Chow LWC, Ngan HYS, Done SJ, Liang ACT, Chan VWY, Au GKH, Ng WF, Poon CSP, Leung YF, Loong F, Ip P, Chan GSW, Andrulis IL, Lu J, Ho FCS 1999. Somatic mutations in the BRCA1 gene in Chinese sporadic breast and ovarian cancer. Oncogene, 18: 46434646.

Kristjansson AK, Eiriksdottir G, Ragnarsson G, Sigurdsson A, Gudmundsson J, Barkardottir RB, Jonasson JG, Egilsson V, Ingvarsson S 1997. Loss of heterozygosity at chromosome $7 \mathrm{q}$ in human breast cancer: association with clinical variables. Anticancer Res, 17: 93-98.

Lee H, Trainer AH, Friedman LS, Thistlethwaite FC, Evans MJ, Ponder BA, Venkitaraman AR 1999. Mitotic checkpoint inactivation fosters transformation in cells lacking the breast cancer susceptibility gene, Brca2. Molec Cell. 4: 1-10.

Lee JS, Collins KM, Brown AL, Lee CH, Chung JH 2000. hCds1-mediated phosphorylation of BRCA1 regulates the DNA damage response. Nature, 404 201-204.

Lingle WL, Barrett SL, Negron VC, D'Assoro AB, Beneman K, Liu W, Whitehead CM, Reynolds C, Salisbury JL 2002. Centromere amplification drives chromosomal instability in breast tumor development. Proc Natl Acad Sci USA, 99: 19781983.

Malkin D, Li FP, Strong LC, Fraumeni JF Jr, Nelson CE, Kim DH, Kassel J, Gryka MA, Bischoff FZ, Tainsky MA, Friend SH 1990. Germ line p53 mutations in a familial syndrome of breast cancer, sarcomas, and other neoplasms. Science, $\mathbf{2 5 0}$ 1233-1238.

Marcus JN, Watson P, Page DL, Narod SA, Lenoir GM, Tonin P, Linder-Stephenson L, Salerno G, Conway TA, Lynch HT 1996. Hereditary breast cancer: pathobiology, prognosis, and BRCA1 and BRCA2 gene linkage. Cancer, 77: 697-709.

Matsuoka S, Huang M, Elledge SJ 1998. Linkage of ATM to cell cycle regulation by the Chk2 protein kinase. Science, 282: 1893-1897.

Matsuoka S, Rotman G, Ogawa A, Shiloh Y, Tamai K, Elledge SJ 2000. Ataxia telangiectasia-mutated phosphorylates Chk2 in vivo and in vitro. Proc Natl Acad Sci USA, 97: 10389-10394.

Meijers-Heijboer H, Van Den Ouweland A, Klijn J, Wasielewski M, De Snoo A, Oldenburg R, Hollestelle A, Houben M, Crepin E, Van Veghel-Plandsoen M,
Elstrodt F, Van Duijn C, Bartels C, Meijers C, Schutte M, McGuffog L, Thompson D, Easton DF, Sodha N, Seal S, Barfoot R, Mangion J, ChangClaude J, Eccles D, Eeles R, Evans DG, Houlston R, Murday V, Narod S, Peretz T, Peto J, Phelan C, Zhang HX, Szabo C, Devilee P, Goldgar D, Futreal PA, Nathanson KL, Weber BL, Rahman N, Stratton MR 2002. Low-penetrance susceptibility to breast cancer due to CHEK2(*)1100delC in noncarriers of BRCA1 or BRCA2 mutations. Nature Genet, 31: $55-59$.

Melchionna R, Chen XB, Blasina A, McGoan CH 2000. Threonine 68 is required for radiation-induced phosphorylation and activation of Cds1. Nature Cell Biol, 2: 762-765.

Miki Y, Swensen J, Shattuck-Eidens D, Futreal PA, Harshman K, Tavtigian S, Liu Q, Cochran C, Bennett LM, Ding W 1994. A strong candidate for the breast and ovarian cancer susceptibility gene BRCA1. Science, 266: 66-71.

Nass SJ, Herman JG, Gabrielson E, Iversen PW, Parl FF, Davidson NE, Graff JR 2000. Aberrant methylation of the estrogen receptor and Ecadherin 5 ' $\mathrm{CpG}$ islands increases with malignant progression in human breast cancer. Cancer Res, 60: $4346-4348$.

Olivier M, Hainaut P 2001. TP53 mutation pattern in breast cancers: searching for clues of environmental carcinogenesis. Sem Cancer Biol, 11: 353-360.

Ragnarsson G, Sigurdsson A, Eiriksdottir G, Barkardottir RB, Jonasson JG, Ingvarsson S 1996. Loss of heterozygosity at chromosome $1 \mathrm{p}$ in human breast cancer: Association with high S-phase, reduced patient survival and deletions at other chromosome regions. Int J Oncol, 9: 731-736.

Rice JC, Massey-Brown KS, Futscher BW 1998. Aberrant methylation of the BRCA1 CpG island promoter is associated with decreased BRCA1 mRNA in sporadic breast cancer cells. Oncogene, 17: 18071812 .

Sard L, Accornero P, Tornielli S, Delia D, Bunone G, Campiglio M, Colombo MP, Gramegna M, Croce CM, Pierotti MA, Sozzi G 1999. The tumorsuppressor gene FHIT is involved in the regulation of apoptosis and in cell cycle control. Proc Natl Acad Sci USA, 96: 8489-8492.

Shieh SY, Ahn J, Tamai K, Taya Y, Prives C 2000. The human homologs of checkpoint kinases Chk1 and Cds1 (Chk2) phosphorylate p53 at multiple DNA damage-inducible sites. Genes Dev, 14: 289-300.

Sigbjörnsdottir BI, Ragnarsson G, Agnarsson BA, Huiping C, Barkardottir RB, Egilsson V, Ingvarsson S 2000. Chromosome $8 \mathrm{p}$ alterations in sporadic and BRCA2 999del5 linked breast cancer. J Med Genet, 37: 342-347.

Signori E, Bagni C, Papa S, Primerano B, Rinaldi M, Amaldi F, Fazio VM 2001. A somatic mutation in the 5, UTR of BRCA1 gene in sporadic breast cancer causes down-modulation of translation efficiency. Oncogene, 20: 4596-4600.

Sigurdsson S, Bodvarsdottir SK, Anamthawat-Jonsson K, Steinarsdottir M, Jonasson JG, Ogmundsdottir HM, Eyfjord JE 2000. p53 abnormality and chromosomal instability in the same breast tumor cells. Cancer Genet Cytogenet, 121: 150-155. 
Siprashvili Z, Sozzi G, Barnes LD, McCue P, Robinson AK, Eryomin V, Sard L, Tagliabue E, Greco A, Fusetti L, Schwartz G, Pierotti MA, Croce CM, Huebner K 1997. Replacement of Fhit in cancer cells suppresses tumorigenicity. Proc Natl Acad Sci USA, 94: 13771-13776.

Skirnisdottir S, Eiriksdottir G, Baldursson T, Barkardottir RB, Egilsson V, Ingvarsson S 1995. High frequency of allelic imbalance at chromosome region 16q22 q23 in human breast cancer: correlation with high PgR and low S-phase. Int J Cancer, 64: 112-116.

Slamon DJ, Leyland-Jones B, Shak S, Fuchs H, Paton V, Bajamonde A, Fleming T, Eiermann W, Wolter J, Pegram M, Baselga J, Norton L 2001. Use of chemotherapy plus a monoclonal antibody against HER2 for metastatic breast cancer that overexpresses HER2. New Engl J Med, 344: 783792.

Smith SA, Easton DF, Evans DG, Ponder BA 1992 Allele losses in the region $17 \mathrm{q} 12-21$ in familial breast and ovarian cancer involve the wild-type chromosome. Nature Genet, 2: 128-131.

Srivastava S, Zhou ZQ, Pirollo K, Blattner W, Chang EH 1990. Germ-line transmission of a mutated p53 gene in a cancer-prone family with $\mathrm{Li}-$ Fraumeni syndrome. Nature, 348: 747-749.

Sullivan A, Yuille M, Repellin C, Reddy A, Reelfs O, Bell A, Dunne B, Gusterson BA, Osin P, Farrell PJ, Yulug I, Evans A, Ozcelik T, Gasco M, Crook T 2002. Concomitant inactivation of $\mathrm{p} 53$ and Chk2 in breast cancer. Oncogene, 21: 1316-1324.

Thompson ME, Jensen RA, Obermiller PS, Page DL, Holt JT 1995. Decreased expression of BRCA1 accelerates growth and is often present during sporadic breast-cancer progression. Nature Genet, 9: 444-450.

Thorlacius S, Struewing JP, Hartge P, Olafsdottir GH, Sigvaldason H, Tryggvadottir L, Wacholder S, Tulinius H, Eyfjord JE 1998. Population-based study of risk of breast cancer in carriers of BRCA2 mutation. Lancet, 352: 1337-1339.

Tirkkonen M, Johannsson O, Agnarsson BA, Olsson H,
Ingvarsson S, Karhu R, Tanner M, Isola J, Barkardottir RB, Borg A, Kallioniemi OP 1997. Distinct somatic genetic changes associated with tumor progression in carriers of BRCA1 and BRCA2 germ-line mutations. Cancer Res, 57: 1222-1227.

Tutt A, Bertwistle D, Valentine J, Gabriel A, Swift S, Ross G, Griffin C, Thacker J, Ashworth A 2001. Mutation in Brca2 stimulates error-prone homology-directed repair of DNA double-strand breaks occurring between repeated sequences. EMBO J, 20: 4704-4716.

Wilson CA, Ramos L, Villasenor MR, Anders KH, Press MF, Clarke K, Karlan B, Chen JJ, Scully R, Livingston D, Zuch RH, Kanter MH, Cohen S, Calzone FJ, Slamon DJ 1999. Localization of human BRCA1 and its loss in high-grade, noninherited breast carcinomas. Nature Genet, 21: 236-240.

Wooster R, Bignell G, Lancaster J, Swift S, Seal S, Mangion J, Collins N, Gregory S, Gumbs C, Micklem G, Barfoot R, Hamoudi R, Patel S, Rice C, Biggs P, Hashim Y, Smith A, Connor F, Arason A, Gudmundsson J, Ficenec D, Kelsell D, Ford D, Tonin P, Bishop DT, Spurr NK, Ponder BAJ, Eeles R, Peto J, Devilee P, Cornelisse C, Lynch H, Narod S, Lenoid G, Egilsson V, Barkardottir RB, Easton DF, Bentley DR, Futreal PA, Ashworth A, Stratton MR 1995. Identification of the breast cancer susceptibility gene BRCA2. Nature, 378: 789-792.

Zanesi N, Fidanza V, Fong LY, Mancini R, Druck T, Valtieri M, Rudiger T, McCue PA, Croce CM, Huebner K 2001. The tumor spectrum in FHITdeficient mice. Proc Natl Acad Sci USA, 98: 10250-10255.

Zochbauer-Muller S, Fong KM, Maitra A, Lam S, Geradts J, Ashfaq R, Virmani AK, Milchgrub S, Gazdar AF, Minna JD 2001. 5' CpG island methylation of the FHIT gene is correlated with loss of gene expression in lung and breast cancer. Cancer Res, 61: $3581-3585$. 